\title{
Analiza mutacji i polimorfizmów w genie FANCD2 u pacjentek chorych na raka jajnika z populacji polskiej
}

\author{
Joanna Moes-Sosnowska, Agnieszka Budziłowska, Jolanta Kupryjańczyk
}

Wstęp. Gen FANCD2 odgrywa ważną rolę w szlaku homologicznej naprawy DNA (HR), zwanej także ścieżką Fanconi anemia (FA), jednak niewiele wiadomo o jego roli w rozwoju raka jajnika i znaczeniu klinicznym. Celem niniejszej pracy była analiza częstości występowania mutacji i polimorfizmów w genie FANCD2 u pacjentek chorych na raka jajnika. Dodatkowo określono kliniczne znaczenie polimorfizmu p. Pro714Leu genu FANCD2.

Materiał i metody. Materiał do analiz stanowiło DNA izolowane ze 198 raków jajnika oraz dodatkowo z krwi obwodowej od pacjentek z rakiem jajnika, u których wykryto zmiany w sekwencji analizowanych genów. Badania wykonywano przy użyciu metody SSCP i bezpośredniego sekwencjonowania wykrytych wariantów. Zbadano 8 kodujących fragmentów genu FANCD2 (z flankującymi sekwencjami intronowymi), zawierających sekwencje miejsc fosforylacji i ubikwitynacji białka FANCD2, tj. eksony 8-13, 19 oraz ekson 23. Kliniczne znaczenie polimorfizmu rs3864017 (p.Pro714Leu) genu FANCD2 zostało określone w grupie 111 chorych na raka jajnika (FIGO II-IV), dla których dostępne były pełne dane kliniczne dotyczące przebiegu choroby. Analizę przeprowadzono na grupach pacjentek leczonych chemioterapią opartą na taksanach z cisplatyną (schemat TP) lub cisplatynie z cyklofosfamidem (schemat PC), z wykorzystaniem jednoczynnikowych i wieloczynnikowych metod statystycznych.

Wyniki. W analizowanej sekwencji genu FANCD2 wykryto dwie nowe, niepublikowane wcześniej mutacje somatyczne (c.990-24 T>G [0,5\%]; c.1129 A >C, p.Lys351GIn [0,5\%]) oraz cztery znane warianty polimorficzne: rs17032283 (5,5\%), rs9809061 (17,5\%), rs3864017 (16,5\%), rs55856815 (5,5\%). Analiza statystyczna nie ujawniła zależności pomiędzy częstością polimorfizmu p.Pro714Leu a odpowiedzią na chemioterapię (CR, PS), ryzykiem zgonu (OS) i ryzykiem wznowy (DFS) w żadnej z analizowanych grup pacjentek.

Wnioski. Wykryto nowe, nieopisane wcześniej mutacje, a także znane warianty polimorficzne genu FANCD2 w DNA u pacjentek chorych na raka jajnika. Nieliczne mutacje (ok. 1\%) stwierdzone w badanym obszarze genu wskazują, że mutacje w genie FANCD2 nie stanowią głównego mechanizmu upośledzania funkcji kodowanego białka w rakach jajnika. Ponadto wykryty wariant polimorficzny genu FANCD2 (p.Pro714Leu) okazał się nie mieć klinicznego znaczenia.

\section{Mutation analysis of the FANCD2 gene in ovarian cancer patients from the Polish population}

Background. The FANCD2 gene plays an important role in the homologous DNA repair pathway (HR), also called Fanconi anemia pathway (FA), however little is known of its role in ovarian cancer development and prognosis. We aimed to analyse mutations and polymorphisms in the FANCD2 gene in ovarian cancer patients. Additionally we evaluated p.Pro714Leu polymorphic variants of the FANCD2 gene with respect to their clinical importance.

Methods. We genotyped 198 ovarian cancer patients from central Poland with the use of PCR-SSCP and direct sequencing methods. Analysis was performed on part of the coding sequence of FANCD2 gene (exons 8-13, 19 and 23), with the fosforylation and monoubiquitatin sites of FANCD2 protein.

\footnotetext{
Zakład Patologii i Diagnostyki Laboratoryjnej

Centrum Onkologii — Instytut im. Marii Skłodowskiej-Curie w Warszawie

Projekt finansowany z grantu MNiSW nr N N301 462038
} 
The prognostic/predictive significance of p.Pro714Leu polymorphic variants was determined in a group of 111 ovarian cancer patients (FIGO stage II-IV) for which complete clinical data were available. The analysis was performed with the use of univariate and multivariate statistical methods for ovarian cancer patients treated with chemotherapy. Results. We found two novel, unpublished mutations of (c.990-24 T> G (0.5\%) and c.1129 A> C, p.Lys351Gln (0.5\%)) within the analysed sequence of the FANCD2 gene. The presence of four previously described polymorphic variants was also confirmed: rs17032283 (5.5\%), rs9809061 (17.5\%), rs3864017 (16.5\%), rs55856815 (5.5\%).

Statistical analysis revealed no relationship between the p.Pro714Leu polymorphism and response to chemotherapy (CR and PS), the risk of death (OS) and the risk of recurrence (DFS) in any of the analysed group of patients.

Conclusions. Our results show novel substitution identified in single ovarian cancer patients for the first time. However the low incidence of mutations (1\%) in the analysed sequence suggests that FANCD2 alterations are not the primary mechanism for disrupting the function of the encoded FANCD2 protein in ovarian cancer patients. Furthermore we found that the p.Pro714Leu polymorphic variants were not associated with clinical endpoints in any of analysed groups.

NOWOTWORY Journal of Oncology 2015; 65, 1: 7-15

Słowa kluczowe: FANCD2, mutacje, polimorfizmy, p.Pro714Leu, rak jajnika, naprawa DNA

Key words: FANCD2, mutation, polymorphism, p.Pro714Leu, ovarian cancer, DNA repair

\section{Wstęp}

Wśród nowotworów żeńskich dróg rodnych rak jajnika charakteryzuje się w krajach rozwiniętych największą śmiertelnością [1]. Słaba przeżywalność związana jest z faktem, że we wczesnych stadiach choroba jest bezobjawowa.W rezultacie $75 \%$ raków jajnika jest wykrywanych w późnym, często przerzutowym stadium (III/IV wg FIGO), w którym rokowania są złe. Skuteczna chirurgiczna cytoredukcja oraz chemioterapia uzupełniająca, podawana przez ok. 18 tygodni po zabiegu, poprawiły znacznie rokowanie. U pacjentek chorych na raka jajnika stosuje się leczenie chemiczne z zastosowaniem związków platyny (cisplatyna, karboplatyna). Związki te uszkadzają DNA poprzez tworzenie adduktów, powstawanie wiązań krzyżowych i podwójnych pęknięć cząsteczki DNA. W odpowiedzi na powstałe uszkodzenia w komórkach dochodzi do aktywacji $\mathrm{m}$. in. szlaku homologicznej naprawy DNA (HR), inaczej zwanego ścieżką Fanconi anemia (FA). Do tego szlaku należy m. in. gen Fanconi anemia, complementation group D2 (FANCD2). Bialleliczne uszkodzenia genów FA powodują zaburzenia tego mechanizmu naprawy DNA, co w konsekwencji prowadzi do śmierci komórki. W rakach jajnika rozpoznaje się wiele różnorodnych zaburzeń w genach, związanych m.in. ze szlakami naprawy DNA oraz apoptozy [2].Wykazano, że mutacje niektórych genów homologicznej ścieżki naprawy DNA, np. genów BRCA1 i BRCA2 (FANCD1), predysponują do rozwoju raka jajnika oraz wykazują związek z rodzinnymi rakami jajnika (dziedziczne mutacje). Zatem wyjaśnienie biologicznego mechanizmu patogenezy raka jajnika, jak również poszukiwanie molekularnych czynników prognostycznych i predykcyjnych dla pacjentek z rakiem jajnika stanowi wyzwanie współczesnej biologii molekularnej.

W niniejszej pracy analizowano sekwencję genu FANCD2. Białko kodowane przez ten gen uczestniczy w naprawie DNA poprzez homologiczną replikację i system omi- jania uszkodzeń przez polimerazy o niskiej wierności kopiowania (TLS) $[3,4]$. Aktywacja FANCD2 w odpowiedzi na uszkodzenie DNA przebiega poprzez monoubikwitynację białka z wykorzystaniem kompleksu jądrowego FA $[5,6]$. Aktywny FANCD2, w formie kompleksu z białkiem FANCI [7], transportowany jest do miejsca uszkodzenia DNA, gdzie kolokalizuje się razem z BRCA1/2, RAD51 i PCNA. Wykazano także kolokalizację z TP53, Ki-67 i cykliną A - markerami proliferacji komórkowej [8]. FANCD2 podlega również fosforylacji poprzez ATM, ATR i CHK1 [9].

Jak dotąd zmiany w sekwencji DNA genu FANCD2 zostały opisane w nielicznych publikacjach. Mutacje FANCD2 (analiza całego genu lub tylko pojedynczych eksonów) opisano u pacjentów z ostrą białaczką szpikową [10], ostrą białaczką limfoblastyczną [11] i rakiem sutka [12]. Niedawna analiza raków jajnika od trzech pacjentów ujawniła istnienie mutacji typu nonsense w genie FANCD2 [13]. Według naszej wiedzy jak dotąd zmiany tego genu nie były oceniane w dużej grupie raków jajnika.

W niniejszej pracy, ze względu na wielkość genu FANCD2 (44 odcinki kodujące), ograniczono analizowany obszar do 8 fragmentów genu. Na podstawie doniesień z literatury wybrano eksony 8-13, 19 oraz ekson 23. W obrębie tych fragmentów znajdują się miejsca monoubikwitynacji oraz fosforylacji białka FANCD2. W piśmiennictwie wykazano, że substytucja lizyny 561 i fosforylacja w miejscach: seryna 331, 717 i treonina 691 są powiązane z monoubikwitynacją białka i opornością komórek na czynniki uszkadzające DNA [14, 15]. Natomiast fosforylacja w miejscu seryny 222 jest niezbędna do aktywacji punktu kontroli cyklu komórkowego fazy ${ }_{\text {II }}{ }^{\prime}[16]$.

\section{Materiał i metody}

Do badań molekularnych wykorzystano DNA uzyskane z 198 mrożonych w ciekłym azocie guzów jajnika. Wykryte 
zmiany weryfikowano w tkance nienowotworowej (była dostępna w 175 przypadkach) w celu określenia, czy są to zmiany somatyczne czy germinalne.

Wiek pacjentek, w którym zdiagnozowano raka jajnika, zawierał się w przedziale od 17 do 88 lat (mediana wieku 53 lata). Guzy jajnika zostały sklasyfikowane pod względem histologicznym według kryteriów Światowej Organizacji Zdrowia (WHO) [17]. Wśród badanych guzów ponad połowę 116 (59\%) stanowiły raki typu surowiczego. Pozostałe to raki typu: śluzowego 12 (6\%), endometrioidalnego 24 (12\%), jasnokomórkowego 19 (10\%), niezróżnicowane 15 (7\%) i innego typu (mieszane, przejściowo-komórkowe) 12 (6\%). Stopień zróżnicowania histologicznego nowotworów (G) został określony w czterostopniowej skali, według kryteriów Brodersa [18]. W badanej grupie znalazły się raki: dobrze zróżnicowane (G1) 14 (7\%), średnio zróżnicowane (G2) 38 (19\%), niskozróżnicowane (G3) 97 (49\%) i przeważnie lub całkowicie niezróżnicowane (G4) 49 (25\%). Stopień zaawansowania nowotworu został określony według kryteriów FIGO [19]. Wśród badanych guzów znalazło się 39 (20\%) w stadium I-IIA, 8 (4\%) w stadium IIB i IIC, 24 (12\%) w stadium IIIA i IIIB, 113 (57\%) w stadium IIIC oraz 14 (7\%) w stadium IV.

Genomowe DNA izolowano z kriostatowych skrawków uzyskanych z zamrożonych $\left(-80^{\circ} \mathrm{C}\right)$ guzów jajnika, o odsetku komórek nienowotworowych nieprzekraczającym 50\%, lub z krwi obwodowej pobranej na EDTA za pomocą zestawu QIAamp (Qiagen, Hilden, Germany).

Badania wykonywano przy użyciu metody reakcji łańcuchowej polimerazy (PCR), metody polimorfizmu konformacji pojedynczych nici DNA (SSCP) oraz bezpośredniego sekwencjonowania wykrytych wariantów. Zbadano 8 kodujących fragmentów genu FANCD2 [GenBank:NG_007311.1], tj. eksony 8-13, 19 oraz ekson 23 (z flankującymi sekwencjami intronowymi). Część sekwencji starterów wykorzystanych do reakcji PCR i sekwencjonowania zaprojektowano z wykorzystaniem programu Primer3, a część uzyskano z publikacji [20] (tab. I).

Badanie klinicznego znaczenia polimorfizmu p.Pro714Leu przeprowadzono w 111 rakach jajnika usuniętych operacyjnie i zamrożonych, przed zastosowaniem jednej z dwóch rodzajów chemioterapii: schemat TP — taxol lub paclitaxel i cisplatyna lub karboplatyna; schemat PC — cisplatyna lub karboplatyna i cyklofosfamid. Dla tej grupy dostępne były pełne dane kliniczne dotyczące przebiegu choroby (tab. II). Raki jajnika pochodziły z 2 ośrodków: Kliniki Nowotworów Narządów Płciowych Kobiecych, Centrum Onkologii — Instytutu Onkologii w Warszawie oraz Kliniki Położnictwa i Ginekologii Akademii Medycznej i Szpitala Bródnowskiego w Warszawie. Większość przypadków to niskozróżnicowane raki surowicze w stadiach klinicznych IIIB, IIIC i IV, niezawierające więcej niż 15\% komórek prawidłowych. Ten sposób selekcji zapewnił możliwie największą jednolitość patologiczną i kliniczną badanej grupy. Dla wszyst- kich przypadków określono immunohistochemicznie status białka TP53 [21]. Definicję całkowitej remisji (CR) przyjęto na podstawie kryteriów Światowej Organizacji Zdrowia (WHO) [22], a wrażliwość na platynę (PS) — zgodnie z terminologią zaproponowaną przez Christiana i Trimblego (1994) [23].

Jednoczynnikowe i wieloczynnikowe analizy statystyczne znaczenia polimorfizmu p.Pro714Leu zostały wykonane w grupach pacjentek leczonych wg schematu TP, PC, jak również w całej grupie pacjentek. Zastosowano model regresji logistycznej Logit (ocena związku z odpowiedzią na chemioterapię: $C R, P S$ ) oraz model proporcjonalnego hazardu Coxa (ocena związku z przeżyciem pacjentek [OS] i czasem wolnym od choroby [DFS]). Dla porównania przeżycia w grupach pacjentek użyto testu log-rank w oparciu o krzywe Kaplana-Meyera.

W wyjściowym modelu wieloczynnikowym znalazły się zmienne: wiek, stopień zaawansowania nowotworu według FIGO, stopień zróżnicowania histologicznego nowotworu, wielkość pozostawionych resztek nowotworu, typ histologiczny nowotworu, status białka TP53, badany polimorfizm. We wnioskowaniu statystycznym przyjęto poziom istotności statystycznej przeprowadzonych testów $\alpha=0,05$. Do obliczeń statystycznych wykorzystano program komputerowy SAS (Statistical Analysis System).

Badanie zostało zatwierdzone przez lokalną komisję etyczną (nr ref. 13/2008).

\section{Wyniki}

W badanych fragmentach genu FANCD2 wykryto dwie nowe somatyczne mutacje oraz potwierdzono obecność 4 znanych zmian polimorficznych: rs17032283, rs9809061, rs3864017, rs55856815 (tab. III).

Obie nowo odkryte mutacje charakteryzowały się 0,5-procentową częstością występowania i zostały zaobserwowane u pojedynczych pacjentek. Pierwszą mutację, tj. heterozygotyczną substytucję c.990-24T>G, stwierdzono w intronie 12. Na fluorogramie (ryc. 1), w guzie 322, przedstawiona jest prawidłowa sekwencja TTT.W guzie 321 widoczne są dwa różne allele TIT i TGGT substytucji c.990-24T>G, co nie jest obserwowane w tkance prawidłowej tego przypadku (mutacja somatyczna). Natomiast druga mutacja, również somatyczna, heterozygotyczna substytucja - c.1129 A>C, została wykryta w eksonie 13. Fluorogram (ryc. 2) przedstawia sekwencję prawidłową AAG w guzie 322. W guzie 486 widoczne są dwa różne allele $\underline{A} A G$ i CAG substytucji c.1129 A >C, co nie jest obserwowane w tkance prawidłowej. Mutacja ta to substytucja typu missense, skutkująca zamianą aminokwasów lizyny na glutaminę w białku — p.Lys351Gln.

Wśród czterech znanych zmian dwie znajdowały się w intronach oraz dwie w eksonie 23. Pierwsza zmiana eksonowa była typu missense (c.2141C>T, p.Pro714Leu) i skutkowała zamianą aminokwasów proliny na leucynę w białku. Natomiast druga zmiana to jednonukleotydowa substytucja typu 
Tabela I. Kliniczno-patologiczna charakterystyka raków badanych pod kątem znaczenia polimorfizmu p.Pro714Leu genu FANCD2 jako czynnika prognostycznego i predykcyjnego

\begin{tabular}{|c|c|c|c|c|c|c|}
\hline \multirow[t]{2}{*}{ Cechy kliniczne } & \multicolumn{2}{|c|}{$\begin{array}{c}\text { Grupa leczona } \\
\text { wg schematu TP } \\
(n=71)\end{array}$} & \multicolumn{2}{|c|}{$\begin{array}{c}\text { Grupa leczona } \\
\text { wg schematu } P C(n=40)\end{array}$} & \multicolumn{2}{|c|}{$\begin{array}{c}\text { Grupa leczona wg schematu T } \\
\text { lub PC }(n=111)\end{array}$} \\
\hline & $\mathrm{n}$ & $\%$ & $\mathrm{n}$ & $\%$ & $\mathrm{n}$ & $\%$ \\
\hline Wiek (mediana) & 71 & & 40 & & 111 & \\
\hline$\leq 53$ lat & 29 & 40,8 & 20 & 50,0 & 49 & 44,1 \\
\hline$>53$ lat & 42 & 59,2 & 20 & 50,0 & 62 & 55,9 \\
\hline Przedział wiekowy & & & & & & \\
\hline Stadium FIGO & 71 & & 40 & & 111 & \\
\hline I-IIIB & 13 & 18,3 & 9 & 22,5 & 22 & 19,8 \\
\hline IIIC, IV & 58 & 81,7 & 31 & 77,5 & 89 & 80,2 \\
\hline Resztki nowotworowe & 71 & & 40 & & 111 & \\
\hline $0 \mathrm{~cm}$ & 15 & 21,1 & 10 & 25,0 & 25 & 22,5 \\
\hline$\leq 2 \mathrm{~cm}$ & 41 & 57,7 & 12 & 30,0 & 53 & 47,7 \\
\hline$>2 \mathrm{~cm}$ & 15 & 21,2 & 18 & 45,0 & 33 & 29,7 \\
\hline Typ histologiczny & 71 & & 40 & & 111 & \\
\hline surowicze & 58 & 81,7 & 33 & 82,5 & 91 & 82,0 \\
\hline inne typy & 13 & 18,3 & 7 & 17,5 & 20 & 18,0 \\
\hline $\begin{array}{l}\text { Stopień zróżnicowania } \\
\text { histologicznego }\end{array}$ & 71 & & 40 & & 111 & \\
\hline G1 i G2 & 7 & 9,8 & 5 & 12,5 & 12 & 10,8 \\
\hline G3 i G4 & 64 & 90,2 & 35 & 87,5 & 99 & 89,2 \\
\hline Akumulacja TP53 & 71 & & 40 & & 111 & \\
\hline nie ma & 28 & 39,4 & 16 & 40,0 & 44 & 39,6 \\
\hline jest & 43 & 60,6 & 24 & 60,0 & 67 & 60,4 \\
\hline $\begin{array}{l}\text { CR - odpowiedź } \\
\text { na chemioterapię }\end{array}$ & 71 & & 40 & & 111 & \\
\hline całkowita remisja & 51 & 71,8 & 25 & 62,5 & 76 & 68,5 \\
\hline inne odpowiedzi & 20 & 28,2 & 15 & 37,5 & 35 & 31,5 \\
\hline $\begin{array}{l}\text { PS - wrażliwość } \\
\text { na platynę }\end{array}$ & 71 & & 40 & & 111 & \\
\hline wrażliwe & 44 & 62,0 & 19 & 47,5 & 63 & 56,8 \\
\hline oporne & 27 & 32,0 & 21 & 52,5 & 48 & 43,2 \\
\hline $\begin{array}{l}\text { Liczba pacjentek } \\
\text { z ryzykiem wznowy }\end{array}$ & 51 & & 25 & & 76 & \\
\hline $\begin{array}{l}\text { Liczba pacjentek } \\
\text { z ryzykiem zgonu }\end{array}$ & 71 & & 40 & & 111 & \\
\hline Ostatni stan kliniczny & 71 & & 40 & & 111 & \\
\hline żyje bez objawów choroby & 10 & 14,1 & 2 & 5,0 & 12 & 10,8 \\
\hline żyje z chorobą & 11 & 15,5 & 3 & 7,5 & 14 & 12,6 \\
\hline zmarła na skutek choroby & 48 & 67,6 & 34 & 85,0 & 82 & 73,9 \\
\hline zmarła z innych przyczyn & 2 & 2,8 & 1 & 2,5 & 3 & 2,7 \\
\hline
\end{tabular}

silence (c.2148C>G, p.Thr716=), niepowodująca zmiany aminokwasów w białku. Szczegółowe częstości występowania genotypów wykrytych zmian zamieszczone są w tabeli IV.

Do analizy klinicznego znaczenia wykrytych zmian (korelacja z odpowiedzią na chemioterapię i przeżyciem pacjentek) wybrano zmianę eksonową, która spełniała kry- terium minimalnej częstości występowania na poziomie 10\%, tj. p.Pro714Leu. Badana zmiana to substytucja jednonukleotydowa c.2141C>T. Zaobserwowano trzy warianty genotypowe: najczęstszą homozygotę - C/C, heterozygotę C/T i rzadką homozygotę - T/T. Wariant C/C, ze względu na najwyższą częstość, stanowił punkt odniesienia do analiz. 
Tabela II. Startery do reakcji PCR dla genu FANCD2 (*Sekwencje starterów wg [20])

\begin{tabular}{|c|c|c|c|}
\hline FANCD2 & Sekwencje Starterów & Temp. przyłączania $\left({ }^{\circ} \mathrm{C}\right)$ & Długość (pz) \\
\hline 8 & $\begin{array}{l}\text { GACCAGAAAGGCTCAGTTCC } \\
\text { TGGAAAAAGCTAATGGATGGA }\end{array}$ & 53 & 249 \\
\hline $9^{*}$ & $\begin{array}{l}\text { CAGCTCTGCATTTCACACGTA } \\
\text { TGCAGTGATAGAACCCCCATA }\end{array}$ & 54 & 265 \\
\hline $10^{*}$ & $\begin{array}{l}\text { TGCCCAGCTCTGTTCAAACC } \\
\text { AGGCAATGACTGACTGACAC }\end{array}$ & 54 & 219 \\
\hline 11 & $\begin{array}{l}\text { AAGTTGAGGTAGTGACATGAAAACC } \\
\text { TGGGGACAGAGAAGAGCAAT }\end{array}$ & 53 & 227 \\
\hline 12 & $\begin{array}{l}\text { CTGGACTGTGCCTACCCACT } \\
\text { CATCCTGTGTGAGGATGAGC }\end{array}$ & 54 & 190 \\
\hline $13^{*}$ & $\begin{array}{l}\text { ATGGCAGGAACTCCGATCTT } \\
\text { CCTTATTCAGCATGCCCTGT }\end{array}$ & 53 & 363 \\
\hline $19^{*}$ & $\begin{array}{l}\text { CATACCTTCTTTTGGTGTGC } \\
\text { CCACAGAAGTCAGAATCTCCACG }\end{array}$ & 53 & 198 \\
\hline $23^{*}$ & $\begin{array}{l}\text { TGGTTTTCCCTGTAGCCTTG } \\
\text { CTCAACTTCCCCACCAAGAG }\end{array}$ & 54 & 294 \\
\hline
\end{tabular}

Tabela III. Częstość występowania wykrytych zmian w genie FANCD2

\begin{tabular}{|c|c|c|c|c|c|c|}
\hline $\mathrm{Nr}$ & $\mathrm{Nr} \mathrm{NCBI}$ & $\begin{array}{c}\text { Zmiana nukleotydu } \\
\text { NM_001018115.1 }\end{array}$ & $\begin{array}{l}\text { Efekt w białku } \\
\text { NP_149075.2 }\end{array}$ & Ekson/intron & Liczba zmian (\%) & Germinalna/somatyczna \\
\hline 1 & 112 - nowa & c. $990-24 T>G$ & - & intron 12 & $1(0,5)$ & somatyczna \\
\hline 2 & Ex13-nowa & c.1129 A >C & p.Lys351Gln & ekson13 & $1(0,5)$ & somatyczna \\
\hline 3 & rs17032283 & c. $695+16 G>C$ & - & intron 9 & $11(5,5)$ & germinalna \\
\hline 4 & rs9809061 & c. $990-38 C>G$ & - & intron 12 & $35(17,5)$ & germinalna \\
\hline 5 & rs3864017 & $c .2141 C>T$ & p.Pro714Leu & ekson 23 & $33(16,5)$ & germinalna \\
\hline 6 & rs55856815 & c. $2148 C>G$ & p.Thr716= & ekson 23 & $11(5,5)$ & germinalna \\
\hline
\end{tabular}

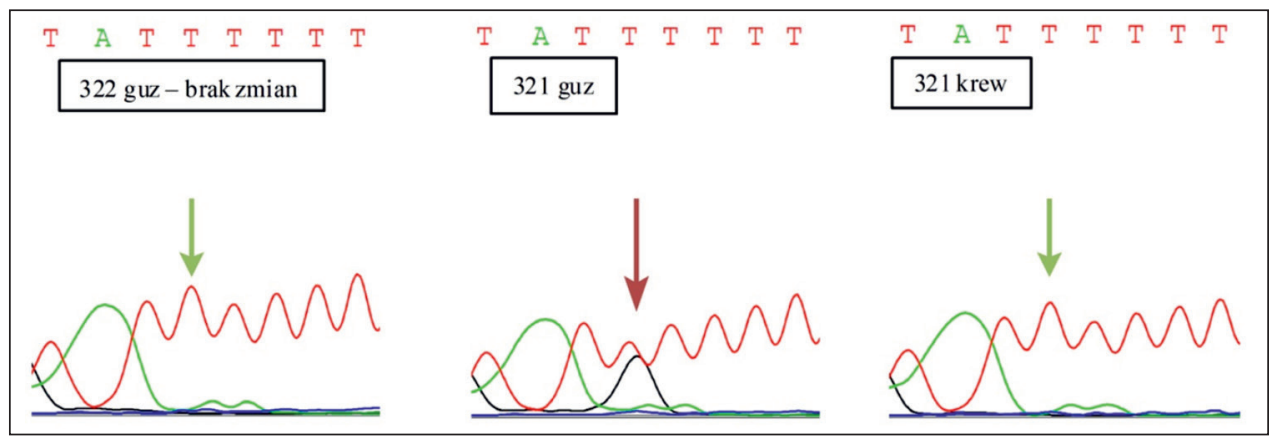

Rycina 1. Zmiana c.990-24T>G w genie FANCD2, intron 12

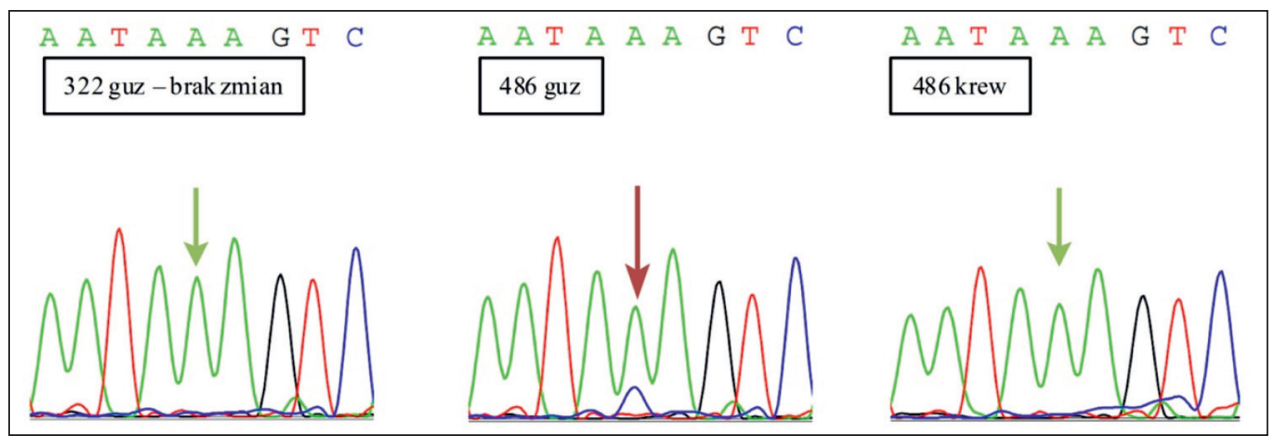

Rycina 2. Zmiana c.1129A >C (p.Lys351Gln) w genie FANCD2, ekson 13 
Tabela IV. Częstość występowania genotypów zmian rs17032283, rs9809061, rs3864017 i rs55856815 genu FANCD2

\begin{tabular}{|c|c|c|c|c|c|c|c|}
\hline \multirow[t]{2}{*}{$\mathrm{Nr}$} & \multirow[t]{2}{*}{ Nr ncbi } & \multirow{2}{*}{$\begin{array}{c}\text { Zmiana nukleotydu } \\
\text { nm_001018115.1 }\end{array}$} & \multirow{2}{*}{$\begin{array}{c}\text { Efekt w białku } \\
\text { np_149075.2 }\end{array}$} & \multicolumn{4}{|c|}{ Częstość występowania (\%) } \\
\hline & & & & homozygota AA & heterozygota $\mathrm{Aa}$ & homozygota aa & $\mathrm{Aa}+\mathrm{aa}$ \\
\hline 1 & rs17032283 & c. $695+16 G>C$ & - & $187(94,5)$ & $7(3,5)$ & $4(2)$ & $11(5,5)$ \\
\hline 2 & rs9809061 & c. $990-38 C>G$ & - & $163(82)$ & $32(16)$ & $3(1,5)$ & $35(17,5)$ \\
\hline 3 & rs3864017 & c. $2141 C>T$ & p.Pro714Leu & $165(83,5)$ & $26(13)$ & $7(3,5)$ & $33(16,5)$ \\
\hline 4 & rs55856815 & c. $2148 C>G$ & p.Thr716= & $187(94,5)$ & $11(5,5)$ & - & $11(5,5)$ \\
\hline
\end{tabular}

Tabela VI. Znane warianty sekwencji genu FANCD2

\begin{tabular}{|c|c|c|c|}
\hline Zmiana & $\begin{array}{l}\text { Częstość występowania } \\
\text { w niniejszej pracy }\end{array}$ & $\begin{array}{c}\text { Częstość występowania w innych pracach } \\
\text { (rak jajnika/grupa kontrolna) }\end{array}$ & $\begin{array}{l}\text { Częstość występowania w innych } \\
\text { pracach (inne nowotwory/ } \\
\text { /grupa kontrolna) }\end{array}$ \\
\hline \multirow[t]{3}{*}{ c. $695+16 \mathrm{G}>\mathrm{C}$} & $5,5 \%$ & - & płaskonabłonkowy rak przełyku \\
\hline & & & $42 \% / /-$ \\
\hline & & & Akbari (2011) [30] \\
\hline \multirow[t]{3}{*}{ c. $990-38 C>G$} & $17,5 \%$ & - & rodzinny rak sutka i jajnika \\
\hline & & & $33 \% / /-$ \\
\hline & & & Lewis (2005) [20] \\
\hline \multirow[t]{6}{*}{ p.Pro714Leu } & $16,5 \%$ & - & rodzinny rak sutka \\
\hline & & & $>10 \% / /-$ \\
\hline & & & Seal (2003) [12] \\
\hline & & & płaskonabłonkowy rak przełyku \\
\hline & & & $33,7 \% / /-$ \\
\hline & & & Akbari (2011) [30] \\
\hline \multirow[t]{3}{*}{ p.Thr716= } & $5,5 \%$ & - & rodzinny rak sutka i jajnika \\
\hline & & & $3 \% / /-$ \\
\hline & & & Lewis (2005) [20] \\
\hline
\end{tabular}

(-) brak danych z literatury

Z uwagi na małą częstość genotypuT/T do analiz statystycznych przeżycia i odpowiedzi na chemioterapię warianty $C / T$ i T/T zostały połączone w jedną zmienną C/T $+T / T$.

Przeprowadzona analiza statystyczna nie ujawniła zależności pomiędzy częstością polimorfizmu p.Pro714Leu a odpowiedzią na chemioterapię (całkowita remisja [CR] i wrażliwość na platynę [PS]) oraz z przeżyciem (ryzyko zgonu [OS] i ryzyko wznowy [DFS]) w żadnej z analizowanych grup (tab. V - tylko w wersji elektronicznej artykułu).

\section{Dyskusja}

Przedstawiona praca jest dotychczas pierwszą próbą oceny mutacji w genie FANCD2 w dużej grupie raków jajnika. W badanym obszarze genu FANCD2 nie wykryto mutacji skutkujących skróceniem białka oraz żadnych zmian w miejscach fosforylacji i ubikwitynacji białka FANCD2 (kodony $222,331,561,691,717)$. Zaobserwowano dwie nowe somatyczne mutacje oraz potwierdzono obecność 4 znanych jednonukleotydowych zmian.

Wykryta mutacja eksonowa p.Lys351GIn znajduje sie w odległości 20 aminokwasów od seryny 331, miejsca fos- forylacji białka powiązanego z ubikwitynacją FANCD2. Natomiast mutacja w intronie 12 (c.990-24T>G) znajduje się w odległości 24 nukleotydów od początku eksonu 13. Wśród opublikowanych dotychczas danych na temat genu FANCD2 nie ma informacji o wymienionych zmianach. Ustalenie ich znaczenia dla funkcji białka wymaga dalszych badań.

Mutacje tego genu wykrywane były przede wszystkim u chorych z zespołem Fanconiego, a także u pacjentów z nowotworami [10-13]. Większość opisywanych mutacji to substytucje w eksonach bądź intronach, skutkujące utworzeniem miejsc inicjujących alternatywny splicing [24, 25]. Wykrywano także duże delecje, często prowadzące do utraty całego eksonu [24, 26]. W raku jajnika opisano niedawno mutację punktową typu nonsense [13].

W niniejszej pracy szczególnie interesujące jest znacznie rzadsze występowanie trzech z czterech zaobserwowanych zmian (tab. Vl) w raku jajnika w porównaniu z innymi nowotworami. Z dostępnej literatury i analizy in silico [27] wynika, że p.Pro714Leu najprawdopodobniej nie wpływa na funkcję białka - posiada neutralny charakter i jest tolerowana. W prezentowanej pracy nie wykazano znaczenia klinicz- 
nego tej zmiany u chorych z rakiem jajnika. Ze względu na niewielką liczbę opublikowanych analiz sekwencji genu FANCD2 potencjalne kliniczne znaczenie znanych wariantów sekwencji tego genu nie jest dostateczne zbadane. Z analizy dostępnej literatury wynika, że dotychczas tylko dla jednego polimorfizmu genu FANCD2 (p.L1366L, ekson 42) wykazano związek z zachorowaniem na raka sutka [28]. Natomiast analiza in silico zmiany p.Thr716= wykazała brak wpływu p.Thr716= na fałdowanie i składanie mRNA, ale wskazała potencjalny wpływ na wzmacniacze ekspresji białka (enhancers).

W interpretacji uzyskanych wyników należy pamiętać o istnieniu ograniczeń w przeprowadzonych badaniach. Ze względu na analizę wybranych fragmentów genu i ograniczoną czułość zastosowanej metody SSCP (w naszym ośrodku stwierdziliśmy 90-procentową czułość SSCP w wykrywaniu pojedynczych substytucji i 100-procentową czułość w wykrywaniu delecji oraz insercji [29]) nie jest wykluczone istnienie innych mutacji w tym genie.

Należy nadmienić także, że w pracy Kalba i wsp. (2007) [24] autorzy wskazują na istnienie dwóch pseudogenów FANCD2 (FANCD2-P1 i -P2) o wysokiej homologii do niektórych eksonów genu. P1 wykazuje homologię do eksonów 1,12-16 i 18, a P2 do eksonów 12-14 i 17-28. W niniejszej pracy badane eksony 8-11 nie znajdowały się w obrębie sekwencji pseudogenów, a dla eksonów 12-13 startery zostały tak zaprojektowane, aby wykrywały tylko sekwencję genu FANCD2.Ze względu na zachowanie sekwencji intronowych w pseudogenie P2 niemożliwe było rozdzielenie sekwencji genu od pseudogenu dla eksonów 19 i 23. Wobec tego nie można wykluczyć, że zmiany znalezione w tych fragmentach mogą dotyczyć jednej z sekwencji lub obu naraz. Sprawdzenie tego wymaga dalszych badań.

\section{Wnioski}

W wyniku analizy sekwencji genu FANCD2 w DNA u pacjentek chorych na raka jajnika wykryto nowe, nieopisane wcześniej mutacje, a także znane warianty polimorficzne. Nieliczne mutacje (ok. 1\%) stwierdzone u pojedynczych pacjentek wskazują, że w rakach jajnika mutacje w badanym obszarze genu nie stanowią głównego mechanizmu upośledzania funkcji kodowanego przez niego białka.

Ponadto wykryty wariant polimorficzny genu FANCD2 (p.Pro714Leu) okazał się nie mieć klinicznego znaczenia.

\section{Konflikt interesów: nie zgłoszono}

\section{Dr n. med. Joanna Moes-Sosnowska}

Zakład Patologii i Diagnostyki Laboratoryjnej

Centrum Onkologii — Instytut im. Marii Skłodowskiej-Curie

ul. Roentgena 5, 02-781 Warszawa

e-mail:joamoes@gmail.com

Otrzymano: 2 września 2014 r.

Przyjęto do druku: 29 października 2014 r.

\section{Piśmiennictwo}

1. Jemal A, Bray F, Center MM i wsp. Global cancer statistics. CA Cancer J Clin 2011; 61: 69-90.

2. Kupryjanczyk J, Siedlecki J. Molekularna patogeneza nowotworów złośliwych. W: Markowska J, (red.) Ginekologia onkologiczna. Tom 1. Wrocław: Urban \& Partner; 2006, 23-43.

3. Taniguchi T, Garcia-Higuera I, Andreassen PR i wsp. S-phase-specific interaction of the Fanconi anemia protein, FANCD2, with BRCA1 and RAD51. Blood 2002; 100: 2414-2420.

4. Fu D, Dudimah FD, Zhang J i wsp. Recruitment of DNA polymerase eta by FANCD2 in the early response to DNA damage. Cell Cycle 2013; 12: 803-809.

5. Garcia-Higuera I, Taniguchi T, Ganesan S i wsp. Interaction of the Fanconi anemia proteins and BRCA 1 in a common pathway. Mol Cell 2001; 7: 249-262.

6. Matsushita N, Kitao H, Ishiai M i wsp. A FancD2-monoubiquitin fusion reveals hidden functions of Fanconi anemia core complex in DNA repair. Mol Cell 2005; 19: 841-847.

7. Smogorzewska A, Desetty R, Saito TT i wsp. A genetic screen identifies FAN1, a Fanconi anemia-associated nuclease necessary for DNA interstrand crosslink repair. Mol Cell 2010; 39: 36-47.

8. van de Groep $\mathrm{P}$, Hoelzel M, Buerger $\mathrm{H}$ i wsp. Loss of expression of FANCD2 protein in sporadic and hereditary breast cancer. Breast Cancer Res Treat 2008; 107: 41-47.

9. Andreassen PR, D'Andrea AD, Taniguchi T. ATR couples FANCD2 monoubiquitination to the DNA-damage response. Genes Dev 2004; 18 1958-1963.

10. Offman J, Gascoigne K, Bristow F i wsp. Repeated sequences in CASPASE-5 and FANCD2 but not NF1 are targets for mutation in microsatellite-unstable acute leukemia/myelodysplastic syndrome. Mol Cancer Res 2005; 3: 251-260.

11. Borriello A, Locasciulli A, Bianco AM i wsp. A novel Leu153Ser mutation of the Fanconi anemia FANCD2 gene is associated with severe chemotherapy toxicity in a pediatric T-cell acute lymphoblastic leukemia. Leukemia 2007; 21: 72-78.

12. Seal $S$, Barfoot $R$, Jayatilake H i wsp. Evaluation of Fanconi Anemia genes in familial breast cancer predisposition. Cancer Res 2003;63:8596-8599.

13. Hoogstraat M, de Pagter MS, Cirkel GA i wsp. Genomic and transcriptomic plasticity in treatment-naive ovarian cancer. Genome Res 2014; 24: 200-211.

14. Ho G, Margossian S, Taniguchi T i wsp. Phosphorylation of FANCD2 on two novel sites is required for mitomycin C resistance. Mol Cell Biol 2006; 26: 7005-7015

15. Zhi G, Wilson JB, Chen X i wsp. Fanconi anemia complementation group FANCD2 protein serine 331 phosphorylation is important for fanconi anemia pathway function and BRCA2 interaction. Cancer Res 2009; 69: 8775-8783.

16. Taniguchi T, Garcia-Higuera I, Xu B i wsp. Convergence of the fanconi anemia and ataxia telangiectasia signaling pathways. Cell 2002; 109: 459-472.

17. Tavassoli FA, Devillee P. Pathology and genetics of tumors of breast and female genital organs WHO Classification of Tumors. Lyon: IARCPress; 2003.

18. Barber HR. Ovarian Cancer. CA Cancer J Clin 1975; 25: 292.

19. Peterson F. Annual report on the results of treatment in gynecological cancer. International Federation of Gynecology and Obstetrics, Stockholm 1988; 20.

20. Lewis AG, Flanagan J, Marsh A i wsp. Mutation analysis of FANCD2, BRIP1/BACH1, LMO4 and SFN in familial breast cancer. Breast Cancer Res 2005; 7: R1005-R1016.

21. Kupryjańczyk J, Szymańska T, Madry R i wsp. Evaluation of clinical significance of TP53, BCL-2, BAX and MEK1 expression in 229 ovarian carcinomas treated with platinum-based regimen. $\mathrm{Br} J$ Cancer 2003; 88: 848-854.

22. Miller A B, Hoogstraten B, Staquet M i wsp. Reporting results of cancer treatment. Cancer 1981; 47: 207-214.

23. Christian MC, Trimble EL. Salvage chemotherapy for epithelial ovarian carcinoma. Gynecol Oncol 1994; 55: 143-150.

24. Kalb R, Neveling K, Hoehn Hi wsp. Hypomorphic mutations in the gene encoding a key Fanconi anemia protein, FANCD2, sustain a significant group of FA-D2 patients with severe phenotype. Am J Hum Genet 2007; 80: 895-910.

25. Ameziane N, Sie D, Dentro S i wsp. Diagnosis of fanconi anemia: mutation analysis by next-generation sequencing. Anemia 2012; 2012: Article ID 132856.

26. Chandrasekharappa SC, Lach FP, Kimble DC i wsp. Massively parallel sequencing, ArrayCGH and RNA-Seq technologies provide a comprehensive molecular diagnosis of Fanconi anemia. Blood 2013; 121: e138-148.

27. LuuTD, Rusu AM, Walter V i wsp. MSV3d: database of human MisSense variants mapped to 3D protein structure. Database 2012; 2012: Article ID bas018.

28. Barroso E, Milne RL, Fernández L P i wsp. FANCD2 associated with sporadic breast cancer risk. Carcinogenesis 2006; 27: 1930-1937.

29. Dansonka-Mieszkowska A, Kluska A, Moes J i wsp. A novel germline PALB2 deletion in Polish breast and ovarian cancer patients. BMCMed Genet 2010; 11: 20 .

30. Akbari M. The role of genetic factors in susceptibility to esophageal squamous cell carcinoma (ESCC). Rozprawa doktorska 2011, Institute of Medical Science University of Toronto. 
Tabela V. Związek polimorfizmu p.Pro714Leu genu FANCD2 z całkowitą remisją (CR), wrażliwością na platynę (PS), czasem całkowitego przeżycia (OS) i czasem wolnym od choroby (DFS)

\begin{tabular}{|c|c|c|c|c|c|c|c|}
\hline \multicolumn{4}{|c|}{ CR Analiza jednoczynnikowa } & \multicolumn{4}{|c|}{ CR Analiza wieloczynnikowa } \\
\hline \multicolumn{8}{|c|}{ Grupa TP, n = 71} \\
\hline $\begin{array}{l}\text { Polimorfizm } \\
\text { p.Pro714Leu }\end{array}$ & $\mathrm{p}$ & $\mathrm{OR}$ & $95 \% \mathrm{Cl}$ & Zmienne pozostałe w modelu & $\mathrm{p}$ & $\mathrm{OR}$ & $95 \% \mathrm{Cl}$ \\
\hline $\mathrm{C} / \mathrm{C}$ & & 1 & & $\mathrm{C} / \mathrm{C}$ & & 1 & \\
\hline \multirow[t]{2}{*}{$\mathrm{C} / \mathrm{T}+\mathrm{T} / \mathrm{T}$} & 0,67 & 1,43 & $0,26-7,79$ & $\mathrm{C} / \mathrm{T}+\mathrm{T} / \mathrm{T}$ & - & - & - \\
\hline & & & & FIGO I-IIIB & 0,07 & 4 & $2-14,28$ \\
\hline \multicolumn{8}{|c|}{$*$ Grupa PC, $n=40$} \\
\hline $\mathrm{C} / \mathrm{C}$ & & 1 & & $\mathrm{C} / \mathrm{C}$ & & 1 & \\
\hline \multirow[t]{4}{*}{$\mathrm{C} / \mathrm{T}+\mathrm{T} / \mathrm{T}$} & 0,9 & 0,88 & $0,12-6,4$ & $\mathrm{C} / \mathrm{T}+\mathrm{T} / \mathrm{T}$ & - & - & - \\
\hline & & & & Typ histologiczny surowiczy & 0,12 & 4,55 & $0,67-33$ \\
\hline & & & & Resztki $0 \mathrm{~cm}$ & 0,15 & 6,25 & $0,83-50$ \\
\hline & & & & Resztki $\leq 2 \mathrm{~cm}$ & 0,9 & 2,27 & $0,48-11,1$ \\
\hline \multicolumn{8}{|c|}{$*$ Grupa TP + PC, $n=111$} \\
\hline $\mathrm{C} / \mathrm{C}$ & & 1 & & $\mathrm{C} / \mathrm{C}$ & & 1 & \\
\hline \multirow{5}{*}{$\mathrm{C} / \mathrm{T}+\mathrm{T} / \mathrm{T}$} & 0,8 & 1,17 & $0,33-4,1$ & $\mathrm{C} / \mathrm{T}+\mathrm{T} / \mathrm{T}$ & - & - & - \\
\hline & & & & Stopień zróżnicowania G1, G2 & 0,18 & 4,35 & $0,53-35,7$ \\
\hline & & & & Typ histologiczny surowiczy & 0,14 & 2,17 & $0,77-6,2$ \\
\hline & & & & Resztki $0 \mathrm{~cm}$ & 0,06 & 3,70 & $0,99-14,3$ \\
\hline & & & & Resztki $\leq 2 \mathrm{~cm}$ & 0,5 & 1,37 & $0,56-3,45$ \\
\hline \multicolumn{4}{|c|}{ PS Analiza jednoczynnikowa } & \multicolumn{4}{|c|}{ PS Analiza wieloczynnikowa } \\
\hline \multicolumn{8}{|c|}{$*$ Grupa TP, $\mathrm{n}=71$} \\
\hline $\begin{array}{l}\text { Polimorfizm } \\
\text { p.Pro714Leu }\end{array}$ & $\mathrm{p}$ & OR & $95 \% \mathrm{Cl}$ & Zmienne pozostałe w modelu & $\mathrm{p}$ & OR & $95 \% \mathrm{Cl}$ \\
\hline $\mathrm{C} / \mathrm{C}$ & & 1 & & $\mathrm{C} / \mathrm{C}$ & & 1 & \\
\hline \multirow[t]{3}{*}{$\mathrm{C} / \mathrm{T}+\mathrm{T} / \mathrm{T}$} & 0,31 & 2,36 & $0,44-12,7$ & $\mathrm{C} / \mathrm{T}+\mathrm{T} / \mathrm{T}$ & - & - & - \\
\hline & & & & Stopień zróżnicowania G1, G2 & 0,13 & 1,38 & $0,64-6,25$ \\
\hline & & & & Brak akumulacji TP53 w guzie & 0,18 & 0,75 & $0,41-1,53$ \\
\hline \multicolumn{8}{|c|}{$\star$ Grupa PC, n $=40$} \\
\hline $\mathrm{C} / \mathrm{C}$ & & 1 & & $\mathrm{C} / \mathrm{C}$ & & 1 & \\
\hline \multirow[t]{4}{*}{$\mathrm{C} / \mathrm{T}+\mathrm{T} / \mathrm{T}$} & 0,55 & 1,78 & $0,25-12,8$ & $\mathrm{C} / \mathrm{T}+\mathrm{T} / \mathrm{T}$ & - & - & - \\
\hline & & & & FIGO I-IIIB & 0,076 & 8,33 & $0,83-100$ \\
\hline & & & & Typ histologiczny surowiczy & 0,19 & 5,26 & $0,43-100$ \\
\hline & & & & Brak akumulacji TP53 w guzie & 0,075 & 3,57 & $0,88-14$ \\
\hline \multicolumn{8}{|c|}{$\star$ Grupa TP + PC, $n=111$} \\
\hline $\mathrm{C} / \mathrm{C}$ & & 1 & & $\mathrm{C} / \mathrm{C}$ & & 1 & \\
\hline \multirow[t]{4}{*}{$\mathrm{C} / \mathrm{T}+\mathrm{T} / \mathrm{T}$} & 0,24 & 2,07 & $0,6-7,17$ & $\mathrm{C} / \mathrm{T}+\mathrm{T} / \mathrm{T}$ & - & - & - \\
\hline & & & & Stopień zróżnicowania G1, G2 & 0,048 & 8,33 & $1,01-100$ \\
\hline & & & & Resztki $0 \mathrm{~cm}$ & 0,034 & 3,57 & $1,1-11$ \\
\hline & & & & Resztki $\leq 2 \mathrm{~cm}$ & 0,46 & 1,39 & $0,57-3,3$ \\
\hline \multicolumn{4}{|c|}{ OS Analiza jednoczynnikowa } & \multicolumn{4}{|c|}{ OS Analiza wieloczynnikowa } \\
\hline \multicolumn{8}{|c|}{$*$ Grupa TP, $\mathrm{n}=71$} \\
\hline $\begin{array}{l}\text { Polimorfizm } \\
\text { p.Pro714Leu }\end{array}$ & $\mathrm{p}$ & $H R$ & & e pozostałe w modelu & $\mathrm{p}$ & & $H R$ \\
\hline $\mathrm{C} / \mathrm{C}$ & & 1 & & $\mathrm{C} / \mathrm{C}$ & & & 1 \\
\hline \multirow[t]{5}{*}{$\mathrm{C} / \mathrm{T}+\mathrm{T} / \mathrm{T}$} & 0,55 & 0,77 & & $\mathrm{C} / \mathrm{T}+\mathrm{T} / \mathrm{T}$ & - & & - \\
\hline & & & & zróżnicowania G1, G2 & 0,057 & & 0,34 \\
\hline & & & & Resztki $0 \mathrm{~cm}$ & 0,022 & & 0,3 \\
\hline & & & & Resztki $\leq 2 \mathrm{~cm}$ & 0,65 & & 0,8 \\
\hline & & & & umulacji TP53 w guzie & 0,053 & & 1,78 \\
\hline
\end{tabular}


Tabela V (cd.). Związek polimorfizmu p.Pro714Leu genu FANCD2 z całkowitą remisją (CR), wrażliwością na platynę (PS), czasem całkowitego przeżycia (OS) i czasem wolnym od choroby (DFS)

\begin{tabular}{|c|c|c|c|c|c|c|}
\hline \multicolumn{7}{|c|}{$\star$ Grupa PC, n $=40$} \\
\hline $\mathrm{C} / \mathrm{C}$ & & 1 & $\mathrm{C} / \mathrm{C}$ & & & 1 \\
\hline \multirow[t]{4}{*}{$\mathrm{C} / \mathrm{T}+\mathrm{T} / \mathrm{T}$} & 0,51 & 0,7 & $\mathrm{C} / \mathrm{T}+\mathrm{T} / \mathrm{T}$ & - & & - \\
\hline & & & Typ histologiczny surowiczy & 0,054 & & 0,27 \\
\hline & & & Resztki $0 \mathrm{~cm}$ & 0,07 & & 0,4 \\
\hline & & & Resztki $\leq 2 \mathrm{~cm}$ & 0,8 & & 1,2 \\
\hline \multicolumn{7}{|c|}{$\star$ Grupa TP + PC, $n=111$} \\
\hline $\mathrm{C} / \mathrm{C}$ & & 1 & $\mathrm{C} / \mathrm{C}$ & & & 1 \\
\hline \multirow[t]{4}{*}{$C / T+T / T$} & 0,36 & 0,73 & $\mathrm{C} / \mathrm{T}+\mathrm{T} / \mathrm{T}$ & - & & - \\
\hline & & & Stopień zróżnicowania G1, G2 & 0,079 & & 0,37 \\
\hline & & & Resztki $0 \mathrm{~cm}$ & 0,006 & & 0,4 \\
\hline & & & Resztki $\leq 2 \mathrm{~cm}$ & 0,60 & & 0,80 \\
\hline \multicolumn{3}{|c|}{ DFS Analiza jednoczynnikowa } & \multicolumn{4}{|c|}{ DFS Analiza wieloczynnikowa } \\
\hline \multicolumn{7}{|c|}{$\star$ Grupa TP, $\mathrm{n}=51$} \\
\hline $\begin{array}{l}\text { Polimorfizm } \\
\text { p.Pro714Leu }\end{array}$ & $\mathrm{p}$ & $\mathrm{HR}$ & Zmienne pozostałe w modelu & & $\mathrm{p}$ & $\mathrm{HR}$ \\
\hline $\mathrm{C} / \mathrm{C}$ & & 1 & $\mathrm{C} / \mathrm{C}$ & & & 1 \\
\hline \multirow[t]{5}{*}{$\mathrm{C} / \mathrm{T}+\mathrm{T} / \mathrm{T}$} & 0,63 & 0,77 & $\mathrm{C} / \mathrm{T}+\mathrm{T} / \mathrm{T}$ & & - & - \\
\hline & & & Stopień zróżnicowania G1, G2 & & 0,1 & 0,28 \\
\hline & & & Resztki $0 \mathrm{~cm}$ & & 0,01 & 0,25 \\
\hline & & & Resztki $\leq 2 \mathrm{~cm}$ & & 0,4 & 0,7 \\
\hline & & & Bez akumulacji TP53 & & 0,03 & 2,29 \\
\hline \multicolumn{7}{|c|}{$\star$ Grupa PC, n $=25$} \\
\hline $\mathrm{C} / \mathrm{C}$ & & 1 & $\mathrm{C} / \mathrm{C}$ & & & 1 \\
\hline $\mathrm{C} / \mathrm{T}+\mathrm{T} / \mathrm{T}$ & 0,66 & 0,71 & $\mathrm{C} / \mathrm{T}+\mathrm{T} / \mathrm{T}$ & & - & - \\
\hline \multicolumn{7}{|c|}{$\star$ Grupa TP + PC, $n=76$} \\
\hline $\mathrm{C} / \mathrm{C}$ & & 1 & $\mathrm{C} / \mathrm{C}$ & & & 1 \\
\hline $\mathrm{C} / \mathrm{T}+\mathrm{T} / \mathrm{T}$ & 0,5 & 0,74 & $\mathrm{C} / \mathrm{T}+\mathrm{T} / \mathrm{T}$ & & - & - \\
\hline
\end{tabular}

